\title{
ERRATUM
}

Danilo D. Fernando • Mark D. Lazzaro

John N. Owens

\section{Growth and development of conifer pollen tubes}

\section{Sex Plant Reprod (2005). DOI: 10.1007/s00497-005-0008-y}

Unfortunately, two references in reference list have been published by mistake. Correct bibliographic citations are given here:

Fernando DD (2005) Characterization of pollen tube development in Pinus strobus (Eastern white pine) through proteomic analysis of differentially expressed proteins. Proteomics (DOI: 10.1002/pmic.200500009) Lazzaro MD, Cardenas L, Bhatt AP, Justus CD, Phillips MS, Holdaway-Clarke TL, Hepler PK (2005) Calcium gradients in conifer pollen tubes: dynamic properties differ from those seen in angiosperms. J Exp Bot 56:2619-2628

The original article can be found at http://dx.doi.org/10.1007/ s00497-005-0008-y

D. D. Fernando $(\bowtie)$

Department of Environmental and Forest Biology,

State University of New York College of Environmental Science

and Forestry, 1 Forestry Drive, Syracuse, NY 13210, USA

E-mail: fernando@esf.edu

Tel.: + 11-315-4706746

Fax: + 11-315-4706934

M. D. Lazzaro

Department of Biology, College of Charleston,

58 Coming Street, Charleston, SC 29424, USA

J. N. Owens

Centre for Forest Biology, University of Victoria,

Victoria, BC V8W 2Y2, Canada 